\title{
MATHEMATICAL MODELING AND EXPERIMENTAL STUDY ON THIN LAYER HALOGEN DRYER OF STRAWBERRY AND STUDY IT'S EFFECT ON ANTIOXIDANT ACTIVITY
}

\author{
Asaad Rehman Saeed Al-Hilphy and Ali Khudhair Jaber AlRikabi \\ Department of Food Sciences, Agriculture College, Basrah Univerisity, Iraq
}

Received 2013-09-05, Revised 2013-09-10; Accepted 2013-09-30

\begin{abstract}
The halogen drying characteristics of strawberry (Fragaria ananassa Duch) slices were investigated. Drying experiments were carried out a three different drying temperatures $\left(60,70\right.$ and $\left.80^{\circ} \mathrm{C}\right)$. The effect of drying temperature on the drying rate, drying coefficient, efficiency, effective diffusivity of the strawberry and antioxidant activity were evaluated. The best model for describing the halogen drying process was chosen by fitting nine commonly used drying models. The effective moisture diffusivity and activation energy were calculated using an infinite series solution of Fick's diffusion equation. The results showed that increasing drying temperature accelerate the halogen drying process. As well as, increasing of drying rate, drying rate constant, drying coefficient and effective diffusivity. All drying experiments had only falling rate period. The goodness of fit tests indicated that the proposed modified page model gave the best fit to experimental results at 70 and $80^{\circ} \mathrm{C}$, but page model gave the best fit to experiment results at temperature of $60^{\circ} \mathrm{C}$. The effective diffusivity varied from $7.53 \times 10^{-9}-2.52 \times 10^{-8}$ $\mathrm{m}^{2} / \mathrm{sec}$. Effective diffusivity was satisfactorily by an Arrhenius type relationship with activation energy with in $60-80^{\circ} \mathrm{C}$ temperature range. The ability of reducing power of the ferrous ion can taken as an indicator for the ability or antioxidant power for strawberry extracted.
\end{abstract}

Keywords: Strawberry, Dehydration, Halogen Dryer

\section{INTRODUCTION}

Strawberries are popular fruits grown in Iraq and many other countries. Strawberries could be consumed fresh or in many others forms, such as juice, concentrate jam, jelly, dried rehydrated with yogurt, bakery products, alcoholic beverage and marmalades (Pallauf et al., 2008). Strawberries have been used in the Spain and Morocco as a traditional medicine (Tahraoui et al., 2007). Natural sun drying is the most common method used to preserve agriculture products in most tropical and sub tropical countries. But natural sun drying isn't possible as a drying method for the Strawberries, because this fruit appears in clusters and ripen in autumn and winter months. In addition hard being unprotected from rain, wind carry dirt, dust, infestation by insects, rodent and other animal (El-Beltagy et al., 2007; Orak et al., 2011). On the other hand natural sun drying application is restricted by the long drying time and need to for favorable weather (Arora, 2006).

There are many methods are used for Strawberries drying, such as the vacuum drying may allow to obtain high quality products, microwave and air drying Evans et al. (2002); Shishehgarha et al. (2002); Taiwo et al. (2003); Askari et al. (2006) and Muthukumaran et al. (2008). As well as freeze drying method is used for drying Strawberries Asami et al. (2003). Evans et al. (2002) stated that the Strawberries is one of the most delicate and highly perishable fruits due to respiration, weight loss and susceptibility to fungal contaminations. Orak et al. (2011) concluded that Strawberries tree fruit is assessable in food industry by drying due to rich Corresponding Author: Asaad Rehman Saeed Al-Hilphy, Department of Food Sciences, Agriculture College, Basrah Univerisity, Iraq 
nutritional components, antioxidant activity and attractive color of the fruit. Strawberries are a good source of antioxidants, which may help reduce the risk of a variety of chronic disease (Marquest et al., 2010). Al-Hilphy et al. (2011) found that the moisture content of the carrot, okra, green peppers and cauliflower has decreased with the increase drying time. There also appeared a constant drying rate and falling drying rate for all vegetables. In addition to that was a good rehydration ratio for all dried vegetables by halogen dryer.

The objective of this study was to investigate the halogen dryer characteristics of the sliced Strawberries to evaluate the effect of halogen dryer conditions on the drying process and to choose the most efficient single layer drying model to describe the drying model, also determine the changes in antioxidant activity and rehydration at different temperatures drying.

\section{MATERIALS AND METHODS}

Fresh strawberry (Fragaria ananassa Duch) samples were procured from agriculture college farm, Basrah, Iraq. After through cleaning and washing, the strawberries were sliced into $10 \mathrm{~mm}$ thickness using a slicer. Moisture content of samples before drying was determined according to the AOAC (1984) and was performed in triplicate. An experimental carried out using halogen dryer for drying strawberry. A digital halogen convection oven made of HE. House Co. was used for strawberry drying. It consist of a byrex ban, it's capacity 201 , glass cover provided with halogen lamp as a heat source, it's energy $1300 \mathrm{~W}$ and fan, it's velocity $1500 \mathrm{rpm}$.

The halogen drying of strawberry slice was carried out at temperature levels 60,70 and $80^{\circ} \mathrm{C}$. The strawberry slices were spread in a single layer on sample tray. Drying data were mounted by using three labeled samples, which were individually weighted. The weights of the labeled sample were recorded every $15 \mathrm{~min}$. throughout the drying test and terminated when the degreases in the weight of the samples had almost ceased. The dried samples were used to determine the final moisture content (equilibrium), the equilibrium moisture content was found by standard hot air oven method (AOAC, 1984).

\subsection{Mathematical Modeling}

Solution of Crank (1975) second law with consider of strawberry a sphere of Radius (R) with initial moisture content $\left(\mathrm{M}_{\mathrm{o}}\right)$ which is uniformly distributed in the sphere and it dried by a constant air flow, temperature, diffusion coefficient, relative humidity. The properties of sphere are constant (Stanislaw et al., 1998; Dimatteo et al., 2000):

$$
\frac{M-M_{e}}{M_{o}-M_{e}}=\frac{6}{\pi^{2}} \sum_{n=1}^{\infty} \exp \cdot\left(\frac{-n^{2} \pi^{2} D_{\text {eff. }} t}{R^{2}}\right)
$$

where, $\mathrm{M}, \mathrm{M}_{\mathrm{o}}, \mathrm{M}_{\mathrm{e}}, \mathrm{D}_{\text {eff }}$ and $\mathrm{t}$ are moisture content, initial moisture content, moisture content in equilibrium with drying air, moisture diffusivity $\left(\mathrm{m}^{2} / \mathrm{sec}\right.$.) and time (sec.). For long drying times, Equation (1) can be simplified to a straight line equation in the form:

$\ln \frac{M-M_{e}}{M_{o}-M_{e}}=\ln \frac{6}{\pi^{2}}-\left(\frac{-n^{2} \pi^{2} D_{\text {eff. }} t}{R^{2}}\right)$

The Moisture Ratio (MR) was calculated using the following Equation (2 and 3):

$M R=\left(\frac{M-M_{e}}{M_{o}-M_{e}}\right)$

Diffusivities are typically determined by plotting experimental drying data in terms of $\ln$ MR versus drying time $(\mathrm{t})$, because the plot gives a straight line with a slope as follows Equation (4):

slop $=\frac{\pi^{2} D_{\text {ef } f}}{R^{2}}$

Average effective moisture diffusivity is calculated from the following Equation (5):

$D_{\text {eff.avarage }}=D_{o} \exp \cdot\left(\frac{-E_{a}}{R T}\right)$

where, $E_{a}$ is the activation energy $(\mathrm{kJ} / \mathrm{KmoL}), \mathrm{D}_{\mathrm{o}}$ is the diffusion coefficient corresponding to infinite temperature $\left(\mathrm{m}^{2} / \mathrm{sec}\right.$.), $\mathrm{T}$ is the absolute drying air temperature $(\mathrm{k})$ and $\mathrm{R}$ is the universal gas constant (8.314 $\mathrm{J} \mathrm{moL}^{-1}$. K).

The well known thin layer drying models related dimensionless moisture ratio as the dry basis moisture content against drying time. The experimental moisture ratio against drying time was fitted in nine thin layer drying models as shown in Table $\mathbf{1 .}$ 
Table 1. Thin layer drying models based on moisture ratio

\begin{tabular}{|c|c|c|}
\hline Model name & Model & References \\
\hline Lewis & $\mathrm{MR}=\exp .(-\mathrm{kt})$ & (Demir et al., 2007; Akpinar, 2006) \\
\hline Page & $\mathrm{MR}=\exp \cdot\left(-\mathrm{kt}^{\mathrm{n}}\right)$ & $\begin{array}{l}\text { (Yaldiz and Ertekin, 2001; Diamente and } \\
\text { Munro,1993) }\end{array}$ \\
\hline Modified Page & $\mathrm{MR}=\exp \cdot\left[(-\mathrm{kt})^{\mathrm{n}}\right]$ & Demiret al.(2007) \\
\hline Henderson and Pabis & $M R=a$ exp. $(-k t)$ & (Henderson and Pabis,1961; Doymaz, 2004) \\
\hline Logarithmic & $M R=\exp \cdot(-k t)+c$ & Akgun and Doymaz (2005) \\
\hline Two-term model & $M R=\exp \cdot\left(-k_{0} t\right)+b \exp \cdot\left(-k_{1} t\right)$ & Madamba and Liboon (2001) \\
\hline Approximation of diffusion & $M R=\exp .(-k t)+(1-a) \exp .(-k b t)$ & Yaldiz and Ertekin (2001) \\
\hline Wang and Singh & $\mathrm{MR}=1+\mathrm{at}+\mathrm{bt}^{2}$ & $\begin{array}{l}\text { (Wang and Singh, 1978; } \\
\text { Sacilik et al., 2006) }\end{array}$ \\
\hline Midilli & $M R=a \exp \cdot\left(-k(t)^{n}\right.$ & Midilli et al. (2002) \\
\hline
\end{tabular}

The coefficient of determination $\left(\mathrm{R}^{2}\right)$ was the primary criterion for selecting the best equation to describe the drying curve equation. The best fit of the experimental data was also selected base on various statistical parameters such as the reduced chi-square $\left(x^{2}\right)$ as the mean square of the deviation between the experimental and predicted values for the models and Root Mean Square Error analysis (RMSE). The highest of the value of the $\mathrm{R}^{2}$ and lowest value of the $\mathrm{x}^{2}$ and RMSE the better the goodness of the fit. The parameter can be calculated as following Equation (6 to 8$)$ :

$$
\begin{aligned}
& R^{2}=\frac{\sum_{i=1}^{n}\left(M R_{\text {pri. }}-\overline{M R_{\text {pri. }}}\right)^{2}}{\sum_{i=1}^{\mathrm{n}}\left(M R_{\text {exp. }}-\overline{M R_{\text {exp. }}}\right)^{2}} \\
& x^{2}=\frac{\sum_{i=1}^{\mathrm{n}}\left(M R_{\text {exp. }}-M R_{\text {pri. }}\right)^{2}}{N-n}
\end{aligned}
$$

$$
\text { RMSE }=\sqrt{\frac{\sum_{i=1}^{N}\left(M R_{\text {pre. }}-M R_{\text {exp. }}\right)^{2}}{N}}
$$

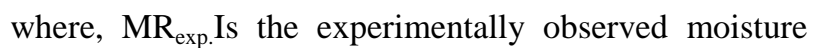
ratio. $\mathrm{MR}_{\text {pre. }}$ Is the predicted moisture ratio, $\mathrm{N}$ is the total number of observation and $\mathrm{n}$ is the number of constants in the model.

Dehydration (Drying) Coefficient (DC) was calculated from the following Equation (9) (Meda and Ratti, 2005):

$$
\mathrm{DC}=\frac{\mathrm{W}_{\mathrm{o}}-\mathrm{W}_{\mathrm{ad}}}{\mathrm{W}_{\mathrm{o}}-\mathrm{W}_{\mathrm{d}}}
$$

where, $\mathrm{W}_{\mathrm{O}}, \mathrm{W}_{\mathrm{ad}}$ and $\mathrm{W}_{\mathrm{d}}$ are the initial weight of the sample, weight after drying and dry mass respectively.
Rehydration ratio $(\mathrm{Rr})$ was calculated according to Rangana (1976) as following Equation (10):

$$
\mathrm{Rr}=\frac{\mathrm{W}_{\mathrm{r}}}{\mathrm{W}_{\mathrm{ad}}}
$$

where, Wr is the dried sample weight after rehydration.

Coefficient of rehydration was determined according to Rangana (1976) using the following Equation (11):

$$
\mathrm{RC}=\frac{\left(100-\mathrm{M}_{\mathrm{wo}}\right) \mathrm{W}_{\mathrm{r}}}{\left(\mathrm{W}_{\mathrm{ad}}-\mathrm{M}_{\mathrm{ad}}\right) \times 100}
$$

where, $\mathrm{M}_{\mathrm{wo}}$ and $\mathrm{M}_{\mathrm{ad}}$ are amount of moisture in the sample befor drying and moisture content present in the dried sample taken for rehydration respectively.

Drying Ratio (DR) has been calculated from the following Equation (12):

$\mathrm{DR}=\frac{\left(100-\mathrm{M}_{\mathrm{ad}}\right)}{\left(100-\mathrm{M}_{\mathrm{o}}\right)}$

Moisture content after rehydration $\left(\mathrm{M}_{\mathrm{r}}\right)$ has been calculated from the following Equation (13):

$M_{r}=\frac{\left(W_{r}-W_{d}\right)}{M_{r}} \times 100$

Water activity $\left(\mathrm{a}_{\mathrm{w}}\right)$ is calculated from Equation (14) (Toledo, 2007):

$\log \frac{a_{w}}{x_{w}}=-k\left(1-x_{w}\right)^{2}$ 
where, $\mathrm{x}_{\mathrm{w}}$ is the mole fraction of water, $\mathrm{k}$ is the constant Equation (15 and 16):

$$
\mathrm{a}_{\mathrm{w}}=\left(\mathrm{a}_{\mathrm{w} 1}\right)^{0}\left(\mathrm{a}_{\mathrm{w} 2}\right)^{0}
$$

$\mathrm{x}_{\mathrm{w}}=1-\mathrm{x}_{\mathrm{s}}$

where, $\mathrm{x}_{\mathrm{s}}$ is the mole fraction of solds.

Drying rate during drying experiments was calculated using the following Equation (17):

$$
\mathrm{DR}=\frac{\mathrm{M}_{\mathrm{t}+\mathrm{dt}}-\mathrm{M}_{\mathrm{t}}}{\mathrm{dt}}
$$

where, $\mathrm{M}_{\mathrm{t}}$ is moisture content at $\mathrm{t}$ and $\mathrm{M}_{\mathrm{t}+\mathrm{dt}}$ is the moisture content at $\mathrm{t}+\mathrm{dt}$.

Drying constant has been produced by modeling of page and modified page equations, it represents to $\mathrm{k}$ constant.

The efficiency ( $\varepsilon$ ) can be defined by Equation (18):

$$
\varepsilon=\frac{\mathrm{T}_{\mathrm{d}}-\mathrm{T}_{\text {out }}}{\mathrm{T}_{\mathrm{d}}-\mathrm{T}_{\mathrm{a}}}
$$

where, $T_{d}$ is the inlet (high) air temperature in to the dryer, $\mathrm{T}_{\text {out }}$ is the out let air temperature from the dryer and $\mathrm{T}_{\mathrm{a}}$ is the ambient air temperature.

\subsection{Determination of Antioxidative Activity}

A $20 \mathrm{mg} \mathrm{mL}^{-1}$ of dried strawberry or BHT was dissolved in $4 \mathrm{ml}$ of $95 \%$ ethanol and mixed with linoleic acid $(2.5 \%$ in ethanol absolute) $(4.1 \mathrm{~mL})$, $0.05 \mathrm{M}$ phosphate buffer $\mathrm{pH} 7.0(8 \mathrm{~mL})$ and distilled water $(3.9 \mathrm{~mL})$ and kept in screw cap containers at 40 $\mathrm{C} / 24 \mathrm{hr}$ in the dark. A $0.1 \mathrm{~mL}$ of $30 \%$ ammonium thiocyanate, added at precisely 3 minute after the addition of $0.1 \mathrm{~m}$ of $20 \mathrm{mM}$ ferrous chloride in $3.5 \%$ hydrochloric acid to the reaction mixture, the absorbance at $500 \mathrm{~nm}$ of the resulting red solution was measured (Yakeda et al., 2012). The percent inhibition of linoleic acid peroxidation was calculated as Anti oxidative activity (\%inhibition $)=($ absorbance of the sample)/absorbance of the control) $\times 100$.

\subsection{Measurement of the Reducing Power}

The dried strawberry $(10,20,30,40$ and $50 \mathrm{mg}$ $\mathrm{mL}^{-1}$ ) or BHT mixed with an equal volume of $0.2 \mathrm{M}$ phosphate buffer ( $\mathrm{pH}$ 6.0) and $1 \%$ potassium ferricyanide. The mixture was incubated at $50^{\circ} \mathrm{C}$ for $20 \mathrm{~min}$. Then an equal volume of $1 \%$ trichloroacetic acid was added to the mixture and centrifuged at 6000 rpm for $10 \mathrm{~min}$. The upper layer of the mixture was mixed with distilled water and $0.1 \% \mathrm{FeCl} 3$ with a ratio of $(1: 1: 2)$ and measured the absorbance at 700 nm (Yen and Chen, 1995).

\subsection{Ferrous Ion Chelating Effect}

Reaction mixtures containing $0.1 \mathrm{mg} \mathrm{mL}^{-1}$ of the dried strawberry, $0.2 \mathrm{~mL}$ of $0.5 \mathrm{mM}$ ferrous $6,5,4,3$, 2, 1 different concentrations (chloride and $0.2 \mathrm{~mL}$ of 5 $\mathrm{mM}$ ferrozine were incubated at $37 \mathrm{Co}$ for $10 \mathrm{~min}$. A $1.5 \mathrm{~mL}$ of deionized water was added to the mixture, the absorbance at $562 \mathrm{~nm}$ was measured (Gibbons and Gray, 1998).

\subsection{Retardation of Corn Oil Auto Oxidation}

$0.5 \mathrm{~g}$ of corn oil was dissolved in $24 \mathrm{~mL}$ of chloroform-methanol mixture $(1: 2)$ and $1 \mathrm{~mL}$ of the dried strawberry was added in various concentrations $(2$, 4, 6, 8 and $10 \mathrm{mg} \mathrm{mL}^{-1}$ ). The dried strawberry was incubated at $45^{\circ} \mathrm{C}$ and peroxide value was determined periodically (Shantha and Decker, 1994).

Statistical analysis: Data were analyzed by ANOVA within a completely randomized design. LSD tests were used for mean discrimination at 0.05 level of probability, using the statistical SPSS software (SPSS, 2009).

\section{RESULTS AND DISCUSSION}

Figure 1 Illustrate the drying curve for three different drying temperature of strawberry $(60,70$ and $80^{\circ} \mathrm{C}$ ). The required drying times to reach mean final moisture content of $0.103,0.076$ and $0.023 \mathrm{~kg} / \mathrm{kg}$. db. for 60,70 and $80^{\circ} \mathrm{C}$ were 75,75 and $60 \mathrm{~min}$. respectively. The temperature $80^{\circ} \mathrm{C}$ required shorter drying time when compared to $60^{\circ} \mathrm{C}$. In other words drying time was reduced to about $20 \%$ for $80^{\circ} \mathrm{C}$ when compared with $60^{\circ} \mathrm{C}$. The drying time reduced significantly $\quad(\mathrm{p}<0.05)$ with increasing drying temperature, because the resistance to moisture movement is relatively higher in reduced temperature than in the higher ones. This resistance is known to degrease drying rate, which resulted in increased drying time of 60 and $70^{\circ} \mathrm{C}$. As expected, increasing the drying temperature degreased the total drying time since heat transfer was increased due to the increasing temperature difference which is the drying potential of the heat transfer (Kaya et al., 2007). 


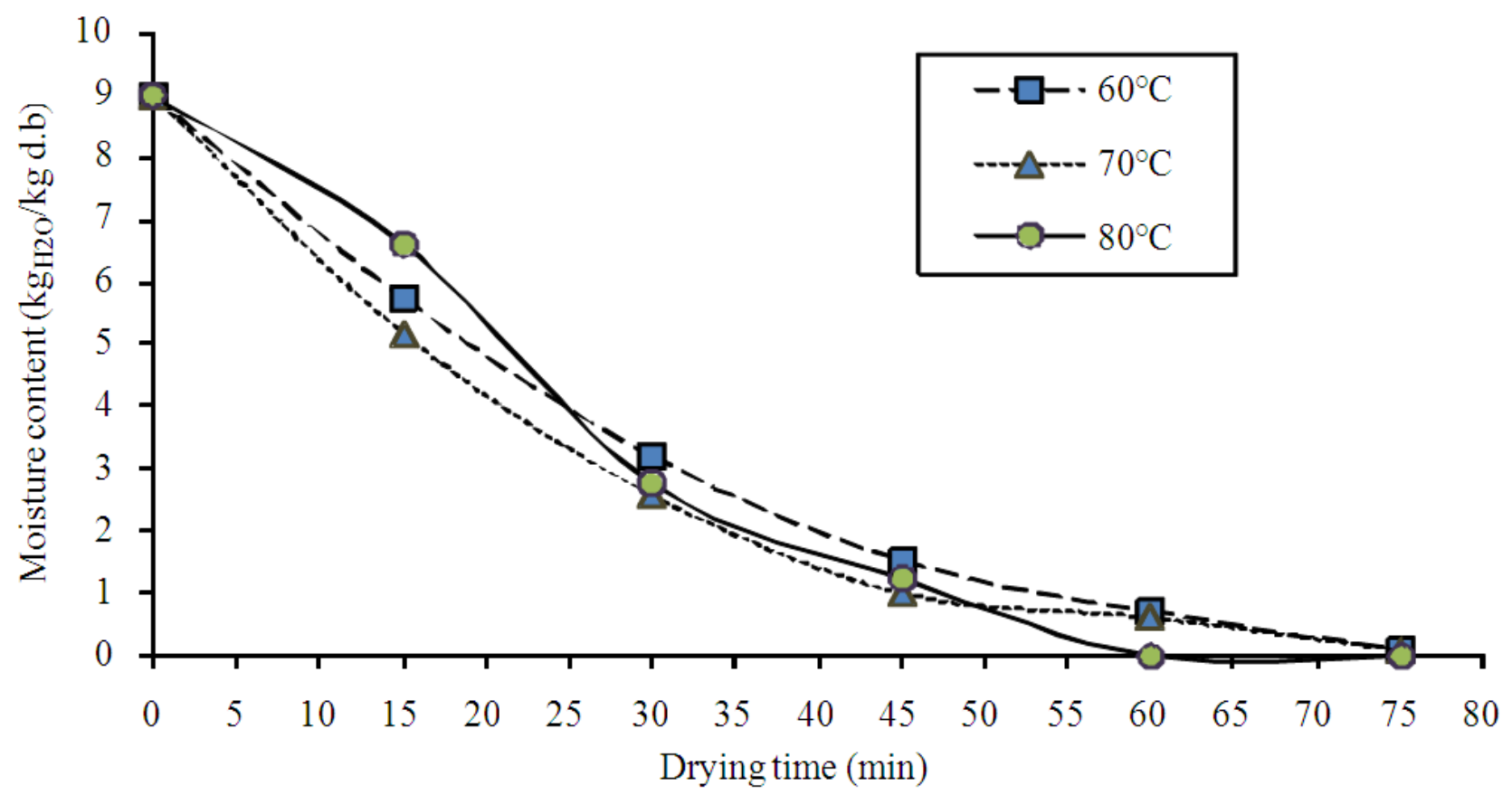

Fig. 1. Drying kinetics of strawberry dried by halogen dryer at different drying temperatures

The moisture content data at the different drying temperatures were converted to the moisture ratio expression and then curve fitting computations with the drying time were done by using nine drying models. The summery of models parameters of nine thin layer drying models that were used for expressing drying characteristics of strawberries sliced dried by halogen dryer at different drying temperatures and the statistical evaluation of models using three different criteria $\left(\mathrm{R}^{2}, \mathrm{x}^{2}\right.$ and $\left.\mathrm{RMSE}\right)$ are presented in the Table 2. In all cases, the values of $\mathrm{R}^{2}$ for the models were greater than 0.8956 , indicating a good fit. Suitability of the models were best on the of $\mathrm{R}^{2}, \mathrm{x}^{2}$ and RMSE values (Thorat et al., 2010). Generally $\mathrm{R}^{2}, \mathrm{x}^{2}$ and RMSE values were changed between 0.8965 and $0.9995,0.0147$ and 6.166, 0.0987 and 2.0275 respectively. It observed that the page model satisfactorily described the drying kinetic of strawberry slices dried under $60^{\circ} \mathrm{C}$. For page model, the $\mathrm{R}^{2}, \mathrm{x}^{2}$ and RMSE values are 0.9994, 0.0180 and 0.1097 respectively. The modified page models was found to be a better model for describing the characteristics of strawberry for both of temperatures 70 and $80^{\circ} \mathrm{C}$. As seen in Fig. 2 the page model showed a good agreement with the experimental results for strawberry slices at temperature $60^{\circ} \mathrm{C}$, but modified page model has a good agreement with the experimental results at temperatures 70 and $80^{\circ} \mathrm{C}$. Figure 3 shows the compares experimental data with these predicted with page model for dried strawberry at temperature of $60^{\circ} \mathrm{C}$. It can be seen also, that Fig. 3 shows the compares experimental data with these predicted with modified page model for dried strawberry at temperatures 70 and $80^{\circ} \mathrm{C}$.

Figure 4 shows drying rate versus moisture content curves. A constant rate period was not observed in any of the experiments of this study, since the entire drying process for strawberry occurs in the range of the falling rate period. The results were generally in agreement with Doymaz (2004); Akpinar (2006); Vagenas and Marinos-Kouris (1991) and Thorat et al. (2010). In the falling rate period the material surface is on larger saturated with water and drying rate is controlled by diffusion of moisture from the interior of sold to the surface (El-Beltagy et al., 2007).

The value of the drying rate constant $(\mathrm{k})$ were determind by fitting data developed in the experiment to page model and modified page model Table 1 and 2. The $\mathrm{k}$ value for different temperatures, the faster the drying rate is the greater the drying constant, $\mathrm{k}$ will be. From Fig. 5, it's apparent that thin layer drying rate increased with increasing drying temperature also, the results showed that the difference between drying coefficient at 70 and $80^{\circ} \mathrm{C}$ is not significant. 
A.R.S. Al-Hilphy and A.K.J. AlRikabi / American Journal of Agricultural and Biological Sciences 8 (4): 268-281, 2013

Table 2. Thin-layer models applied to the drying curves at different drying temperatures

\begin{tabular}{|c|c|c|c|c|c|}
\hline Model & Temperature & Constants & RMSE & $\mathrm{R}^{2}$ & $X^{2}$ \\
\hline \multicolumn{6}{|l|}{ Lewis } \\
\hline & 60 & $\mathrm{k}=0.0372$ & 0.3679 & 0.9955 & 0.1624 \\
\hline & 70 & $\mathrm{k}=0.0433$ & 0.2670 & 0.9975 & 0.0855 \\
\hline & 80 & $\mathrm{k}=0.0378$ & 0.7663 & 0.9817 & 0.7047 \\
\hline \multicolumn{6}{|l|}{ Page } \\
\hline & 60 & $\mathrm{k}=0.0127, \mathrm{n}=1.3087$ & 0.1097 & 0.9994 & 0.0180 \\
\hline & 70 & $\mathrm{k}=0.0198, \mathrm{n}=1.2320$ & 0.0989 & 0.9995 & 0.0147 \\
\hline & 80 & $\mathrm{k}=0.0027, \mathrm{n}=1.7650$ & 0.1797 & 0.9986 & 0.0484 \\
\hline \multicolumn{6}{|l|}{ Modified page } \\
\hline & 60 & $\mathrm{n}=0.9209, \mathrm{k}=0.1137$ & 2.0275 & 0.8956 & 6.1661 \\
\hline & 70 & $\mathrm{n}=1.2320, \mathrm{k}=0.0415$ & 0.0987 & 0.9995 & 0.0147 \\
\hline & 80 & $\mathrm{n}=1.7650, \mathrm{~K}=0.0354$ & 0.1797 & 0.9986 & 0.0484 \\
\hline \multicolumn{6}{|l|}{ Handerson } \\
\hline \multirow[t]{3}{*}{ and pabis } & 60 & $\mathrm{a}=1.0266, \mathrm{k}=0.0381$ & 0.3531 & 0.9948 & 0.1870 \\
\hline & 70 & $\mathrm{a}=1.0165, \mathrm{k}=0.0439$ & 0.2594 & 0.9972 & 0.1009 \\
\hline & 80 & $\mathrm{a}=1.0577, \mathrm{k}=0.0396$ & 0.7318 & 0.9797 & 0.8034 \\
\hline \multicolumn{6}{|l|}{ Logarithmic } \\
\hline & 60 & $\mathrm{a}=1.1622, \mathrm{k}=0.0277, \mathrm{c}=-0.1541$ & 0.1213 & 0.9992 & 0.0294 \\
\hline & 70 & $\mathrm{a}=1.0801, \mathrm{k}=0.0368, \mathrm{c}=-0.0738$ & 0.1414 & 0.9990 & 0.0400 \\
\hline & 80 & $\mathrm{a}=1.2787, \mathrm{k}=0.0253, \mathrm{c}=-0.2431$ & 0.5013 & 0.9891 & 0.5026 \\
\hline \multirow[t]{3}{*}{ Two -term model } & 60 & $\mathrm{a}=0.0141, \mathrm{k} 0=0.0381, \mathrm{~b}=1.0125, \mathrm{k} 1=0.0381$ & 0.3531 & 0.9948 & 0.3740 \\
\hline & 70 & $\mathrm{a}=0.0139, \mathrm{k} 0=0.0439, \mathrm{~b}=1.0026, \mathrm{k} 1=0.0439$ & 0.2594 & 0.9972 & 0.2018 \\
\hline & 80 & $\mathrm{a}=0.0139, \mathrm{k} 0=0.0396, \mathrm{~b}=1.0438, \mathrm{k} 1=0.0396$ & 0.7318 & 0.9797 & 1.6067 \\
\hline Approximation & 60 & $\mathrm{a}=5.9439, \mathrm{k}=0.0635, \mathrm{~b}=1.1519$ & 0.1220 & 0.9993 & 0.0298 \\
\hline \multirow[t]{2}{*}{ of diffusion } & 70 & $\mathrm{a}=7.7221, \mathrm{k}=0.0704, \mathrm{~b}=1.0953$ & 0.1007 & 0.9995 & 0.0203 \\
\hline & 80 & $\mathrm{a}=7.7221, \mathrm{k}=0.0704, \mathrm{~b}=1.0953$ & 0.6372 & 0.9866 & 0.8120 \\
\hline \multirow[t]{3}{*}{ Wang and Singh } & 60 & $\mathrm{a}=-0.0264, \mathrm{~b}=0.0002$ & 0.1419 & 0.9991 & 0.0302 \\
\hline & 70 & $a=-0.0298, b=0.0002$ & 0.2714 & 0.9970 & 0.1105 \\
\hline & 80 & $\mathrm{a}=-0.0274, \mathrm{~b}=0.0002$ & 0.4153 & 0.9937 & 0.2588 \\
\hline \multirow[t]{3}{*}{ Midilli } & 60 & $\mathrm{a}=0.9978, \mathrm{k}=0.0125, \mathrm{n}=1.3119, \mathrm{~b}=0$ & 0.1094 & 0.9995 & 0.0359 \\
\hline & 70 & $\mathrm{a}=0.9992, \mathrm{k}=0.0198, \mathrm{n}=1.2329, \mathrm{~b}=0$ & 0.0988 & 0.9995 & 0.0293 \\
\hline & 80 & $\mathrm{a}=1.0034, \mathrm{k}=0.0028, \mathrm{n}=1.7571, \mathrm{~b}=0$ & 0.1793 & 0.9986 & 0.0964 \\
\hline
\end{tabular}

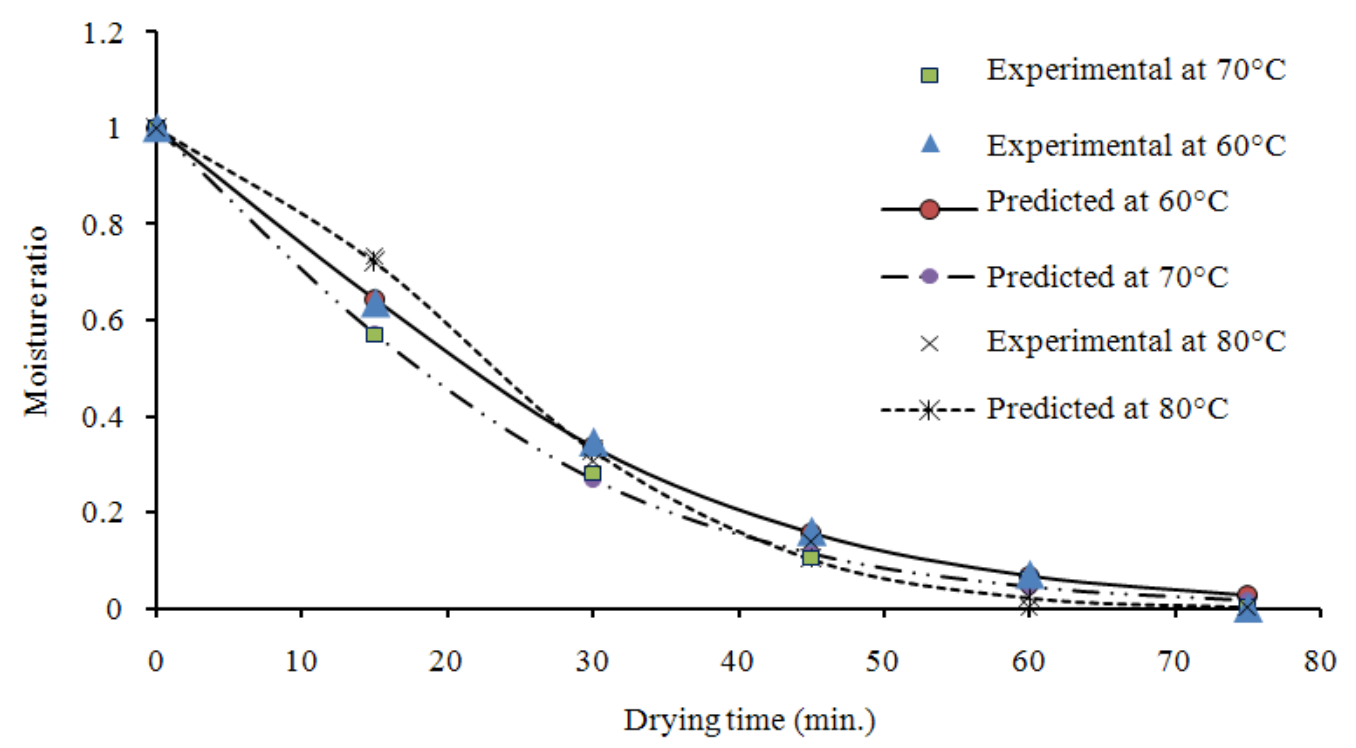

Fig. 2. Page model to the drying strawberry by halogen dryer at temperature of $60^{\circ} \mathrm{C}$ and modified page model to the drying data at 70 and $80^{\circ} \mathrm{C}$ 
A.R.S. Al-Hilphy and A.K.J. AlRikabi / American Journal of Agricultural and Biological Sciences 8 (4): 268-281, 2013

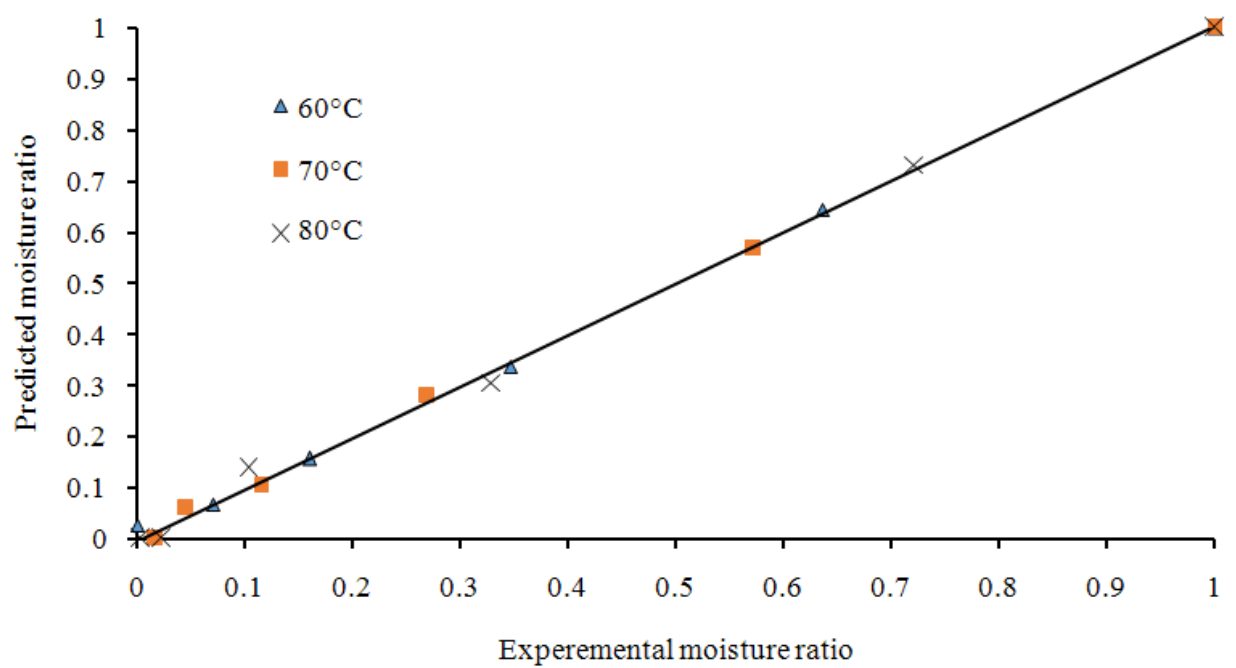

Fig. 3. Experimental and predicted dryng curves for strawberry slices by page model at $60^{\circ} \mathrm{C}$ and modified page model at 70 and $80^{\circ} \mathrm{C}$

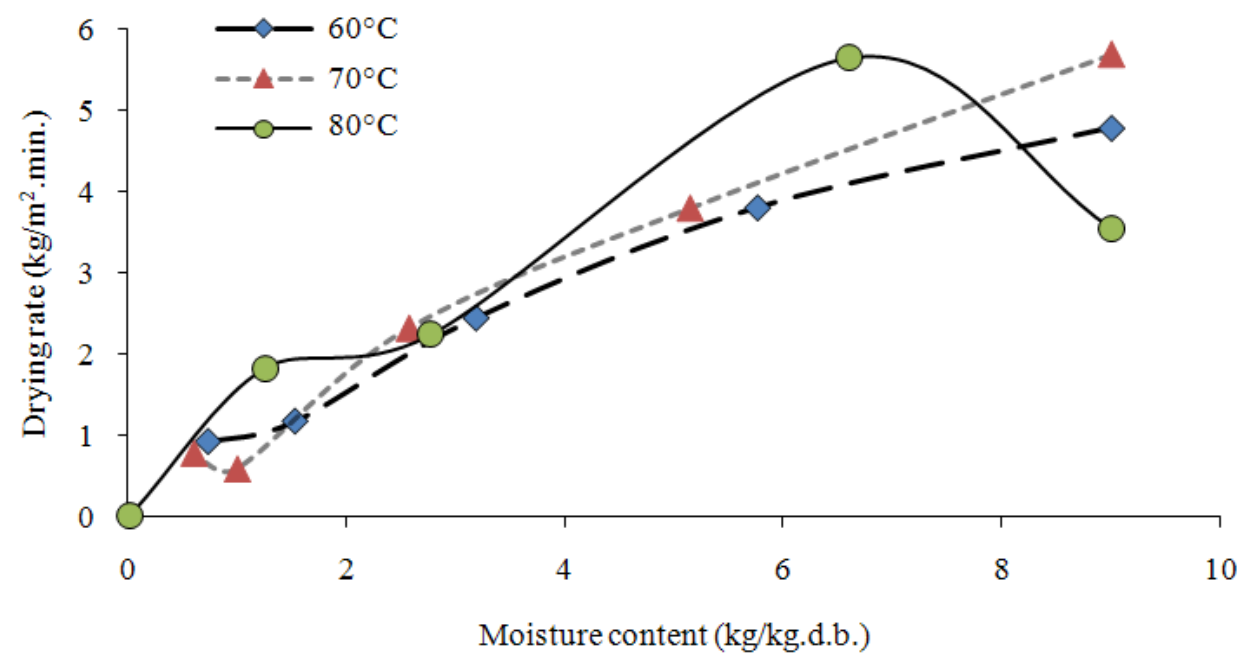

Fig. 4. Variation in drying rate with miosture content of strawberries at different temperaturs

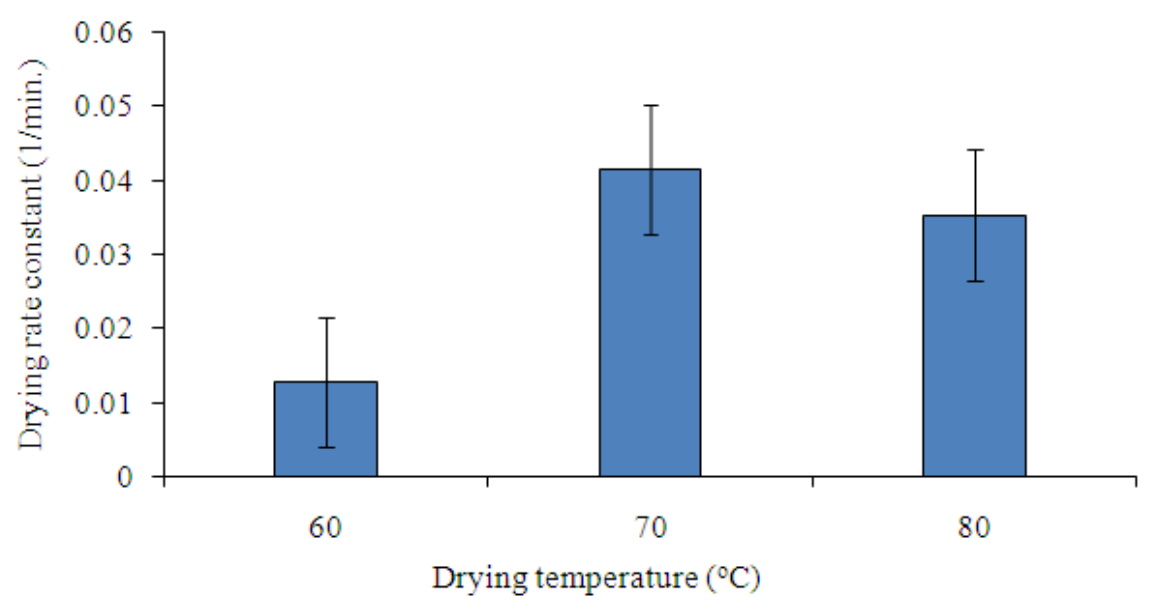

Fig. 5. Drying rate constant vs. drying temperature for dried strawberry by halogen dryer 
The result for drying coefficient vs. drying temperature as shown in Fig. 6. Drying coefficient was increased significantly $(\mathrm{p}<0.05)$ with increasing drying temperature. This due to increasing of the quantities of water eliminated by halogen dryer at increasing temperature to the initial as shown in the Equation (9). It can be seen also, the maximum drying coefficient occurred at temperature $80^{\circ} \mathrm{C}$.

Figure 7 Illustrates the effect of drying temperature on the efficiency based heat input and output in drying air using halogen dryer. The effeicency was significantly $(\mathrm{p}<0.05)$ degreased with increasing drying tempetature. This due to increasing drying temperature and constant the strawberry initial temperature, this led to increasing the difference between them as shown in Equation (18).

On the other hand the results showed in Fig. 8 that the water activity of the fresh strawberry was found to be 0.993 . As after drying, the water activity values reduced to $0.222099, \quad 0.118015$ and 0.00152 corresponding to the moisture content 0.102974828 , 0.07611035 and 0.023091725 respectively. It's observed that there was no significant difference in the water activity among temperatures 60, 70 and $80^{\circ} \mathrm{C}$. Beaudry et al. (2004) reported that there was no significant difference in the water activity of the dried cranberries. The water activity is a function of moisture content in food and temperature and water connection in food can be defined by water activity as water activity for free water, loosely bound water, moderately bound water and tightly bound water are $1,>0.2,0.3<\mathrm{a}_{\mathrm{w}}<0.7,<0.3$ respectively (BarbosaCanovas and Vega-Mercado, 1996).

Figure 9 shows effective diffusivity for dried strawberry at different drying temperature. The average values of effective diffusivities of strawberry slices in the drying process at $60-80^{\circ} \mathrm{C}$ varied in the range of $7.53 \times 10^{-9}-2.52 \times 10^{-8} \mathrm{~m}^{2} / \mathrm{sec}$. The effective diffusivity increased with increase of drying temperature. The internal mass transfer resistance controls the drying time due to the presence of falling rate drying period (Thorat et al., 2010). On the other hand, the variation of $\ln (\mathrm{D})$ with $(1 / \mathrm{T})$ is plotted in Fig. 10. From which $E_{a}$ and $D_{o}$ coefficients are predicted, where the slope of the curve gives the $\left(E_{a} / R\right)$ while the intercept gives $D_{o}$ value.

One of the most important characteristics of dried product is the capacity of rapid and complete rehydration vs. time at 60,70 and $80^{\circ} \mathrm{C}$ is shown in Fig. 11. The rehydration test show that the rehydration at $70^{\circ} \mathrm{C}$ is faster than other temperatures.
This could be due to did not produce a surface casting on the dried strawberry at $70^{\circ} \mathrm{C}$ the analysis of variance indicated that there was a significant in rehydration ratios between 70 and $60^{\circ} \mathrm{C}$ but there was no significant between 70 and $80^{\circ} \mathrm{C}$. The higher rehydration ratio for dried strawberry at $70^{\circ} \mathrm{C}$ indicated that the samples retained good texture and absorbed more water when compared to other temperatures dried samples.

Figure 12 Show the evolution of the rehydration coefficient as a function of rehydration time for 60,70 and $80^{\circ} \mathrm{C}$ of dried strawberry. A twenty minute were necessary to fully rehydrate of strawberry which dried at $70^{\circ} \mathrm{C}$. While for dried strawberry at $60^{\circ} \mathrm{C}$, is higher than 30 min. Fig. 13. Indicate the moisture content vs. drying time for different drying temperatures. The maximum time required to moisture content (w.b.) reach to $75 \%$ is $20 \mathrm{~min}$ for dried strawberry at 70 and $80^{\circ} \mathrm{C}$. But moisture content after rehydration for dried strawberry is $70 \%$ after $30 \mathrm{~min}$. The result showed that no significant differences between moisture content after rehydration for dried strawberry at 70 and $80^{\circ} \mathrm{C}$.

The effective antioxidant was measured for dried strawberry samples at different temperatures are 40 , 60 and $80^{\circ} \mathrm{C}$ and effective antioxidant values were reached to 63,63 and $63 \%$ respectively. Therefore, only one treatment was adopted to complete of study by extraction of antioxidant compounds using solvents and measurement of their ability to seize the ferrous ion, as well as measuring of reduction ability of these compounds and it's application on the corn oil to identification of these compounds ability to oxidation Retardation of corn oil for different storage periods.

Table 3 Shows the development of effective antioxidation of linoleic acid by extracted phenolic compounds from dried strawberry. Has got a rapid increase in the effectiveness of antioxidant in first extraction periods, then got a reduction in the period of extraction later. Reached maximum effectiveness after $30 \mathrm{hr}$ of extraction, the increase is due in anti oxidative activity to the formation antioxidant compounds, the decline in antioxidative activity at prolonging the extraction attributable to two reasons. Two broken the compounds with antioxidant effect in the periods in the first extraction periods or encouraging material is configured to cause oxidative stress with antioxidant compounds previously formed leading to a reduction antioxidant activity ( $\mathrm{Yu}$ et al., 2002). 
A.R.S. Al-Hilphy and A.K.J. AlRikabi / American Journal of Agricultural and Biological Sciences 8 (4): 268-281, 2013

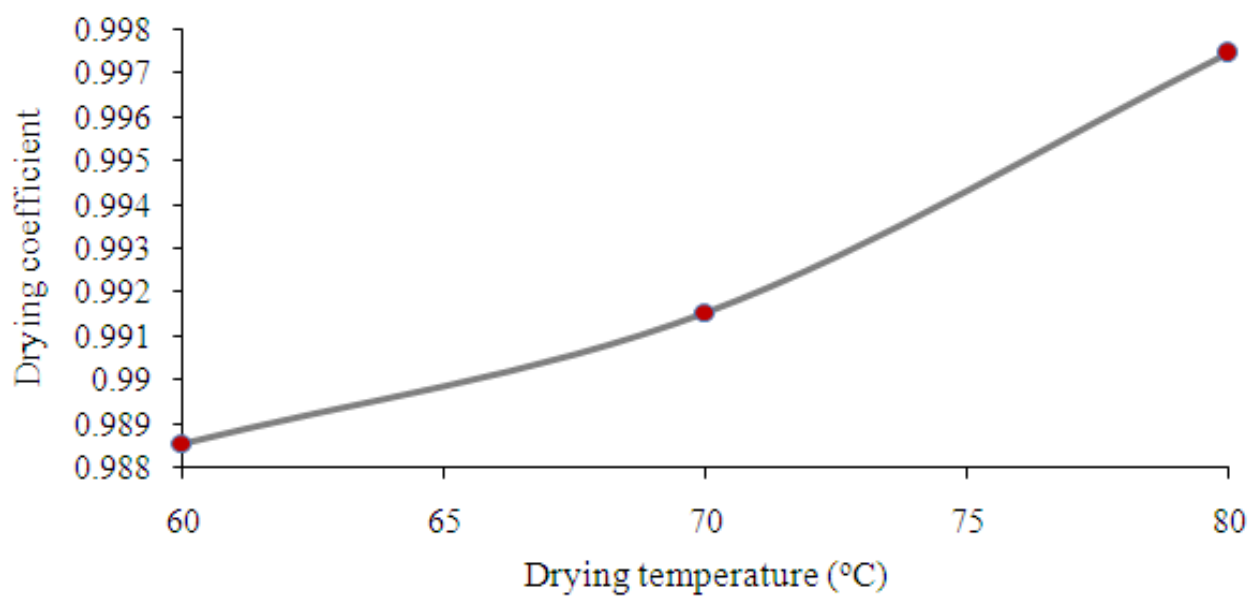

Fig. 6. Drying coefficent vs. drying temperature for dried strawberry by halogen dryer

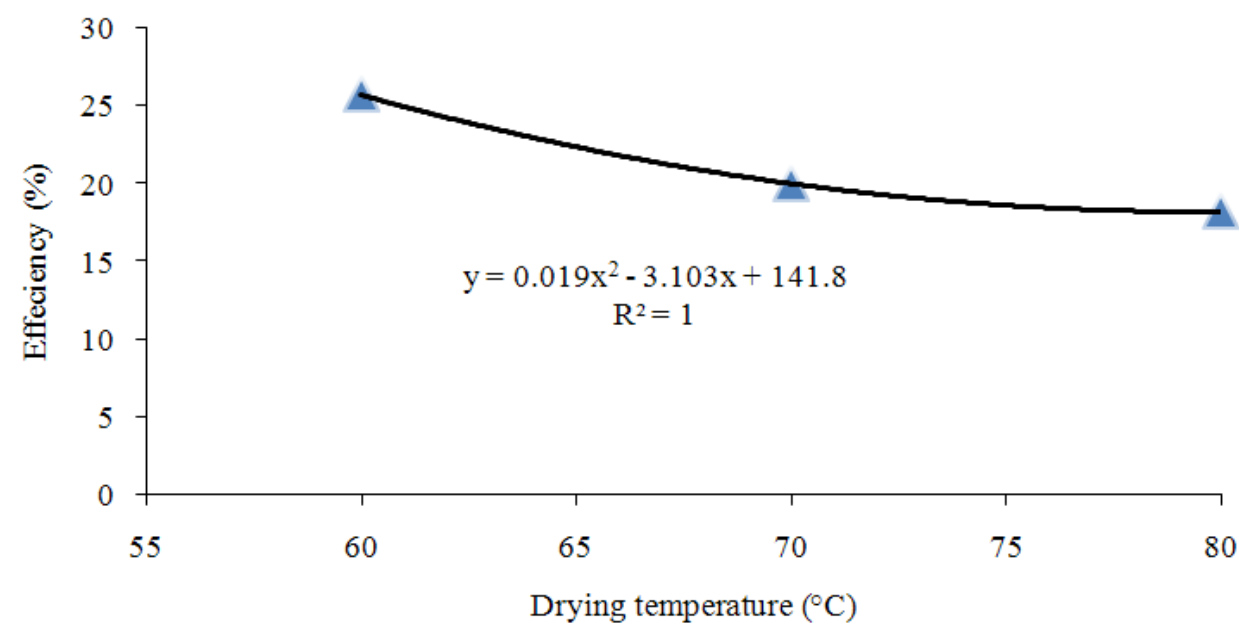

Fig. 7. Efficiency vs. drying temperature for dried strawberry by halogen dryer

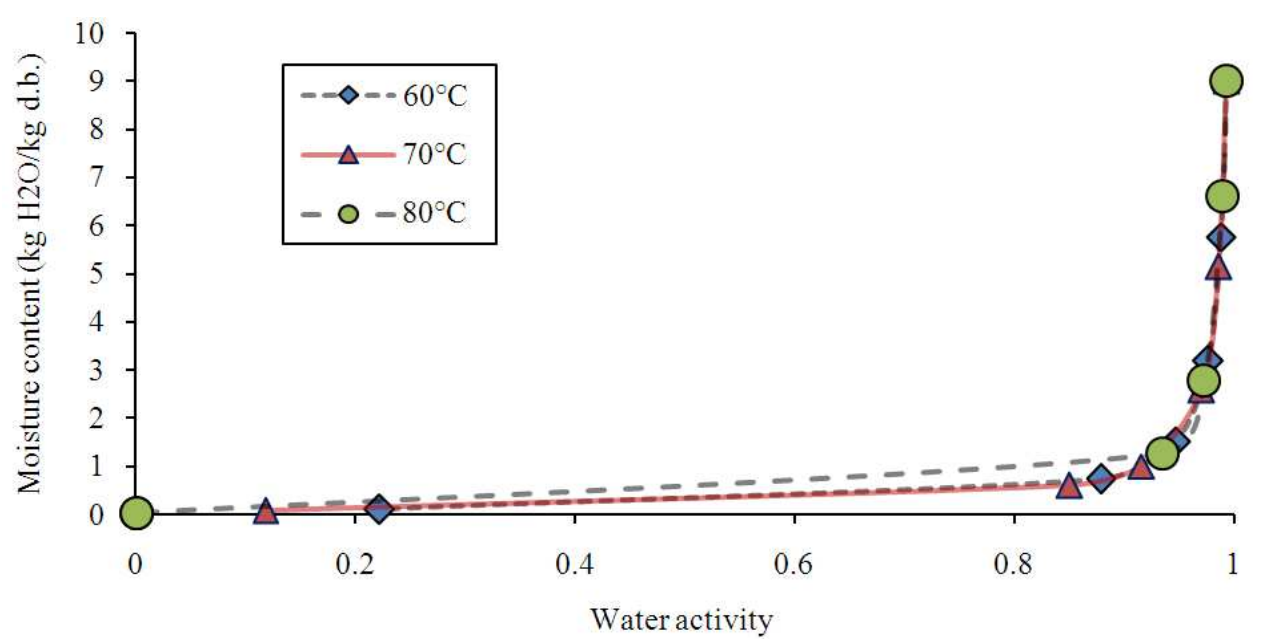

Fig. 8. Moisture sorption isotherm of dried strawberry using different drying temperatures 
A.R.S. Al-Hilphy and A.K.J. AlRikabi / American Journal of Agricultural and Biological Sciences 8 (4): 268-281, 2013

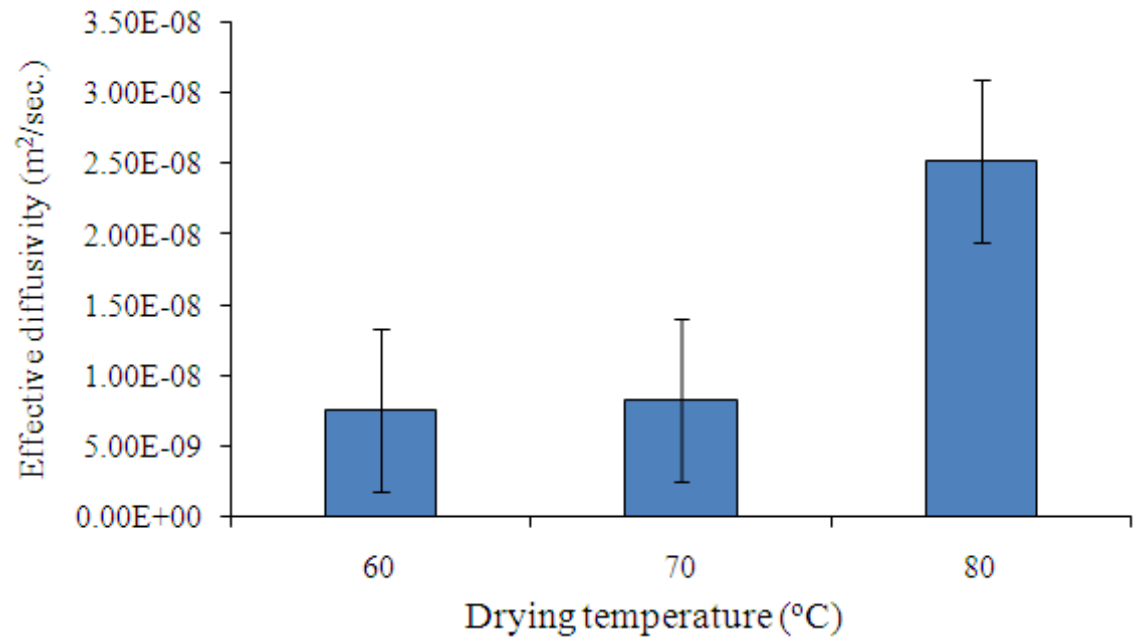

Fig. 9. Effective diffussivity for dried strawberry by halogen dryer at different temperaturs Vs drying temperature

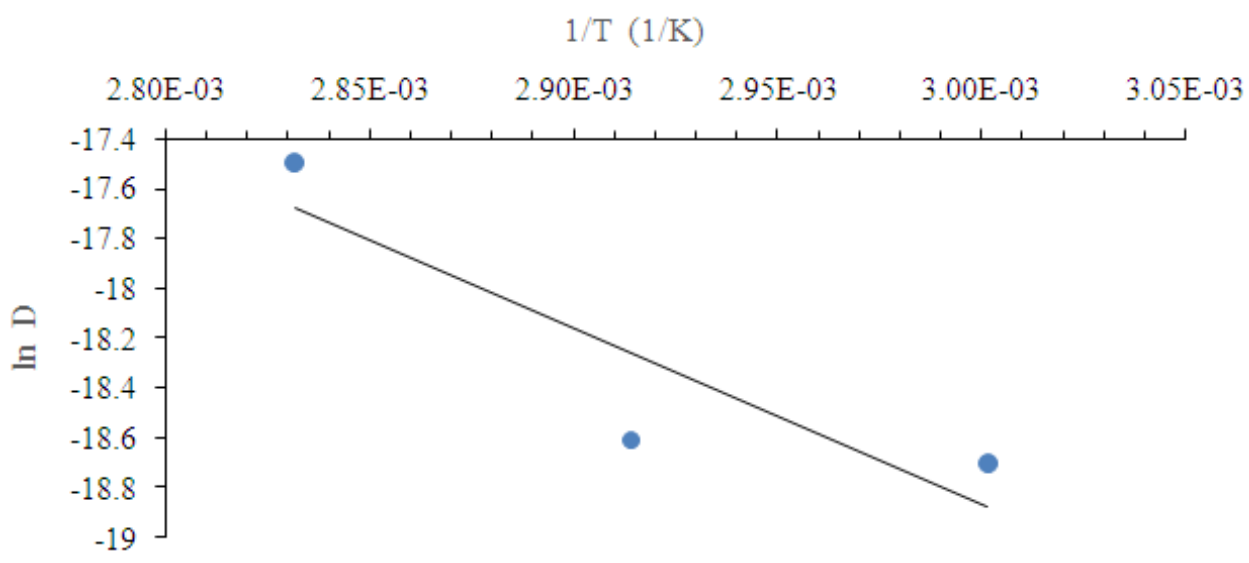

Fig. 10. Arrhenius type relationship between effective moisture diffussivity and tempetrature

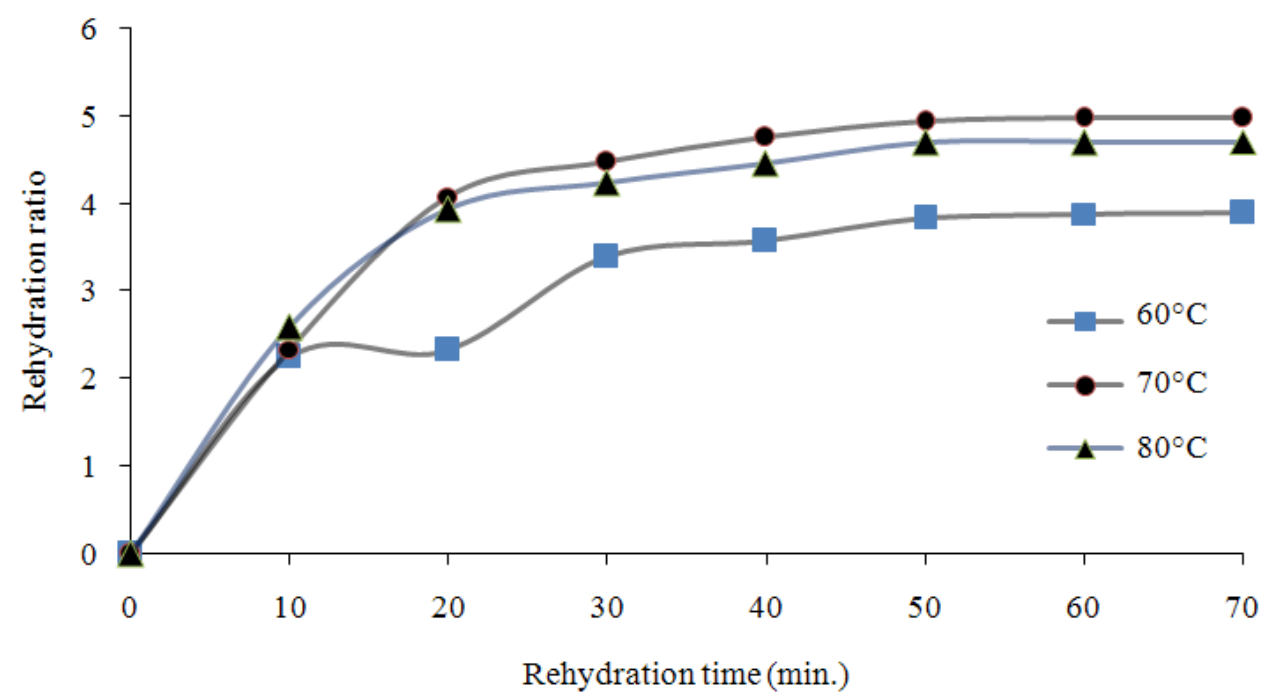

Fig. 11. Rehydration ratio for dried strawberry by halogen dryer at different temperaturs. vs. rehydration time 
A.R.S. Al-Hilphy and A.K.J. AlRikabi / American Journal of Agricultural and Biological Sciences 8 (4): 268-281, 2013

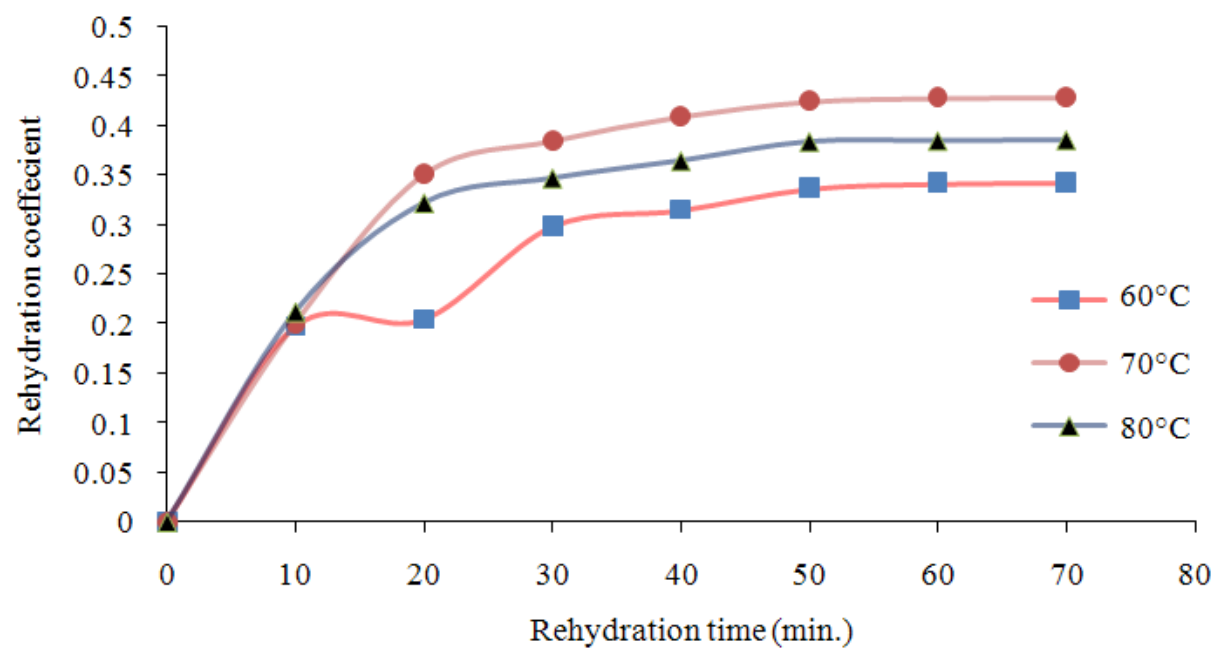

Fig. 12. Rehydration coeffiicient for dried strawberry by halogen dryer at different temperaturs Vs rehydration time

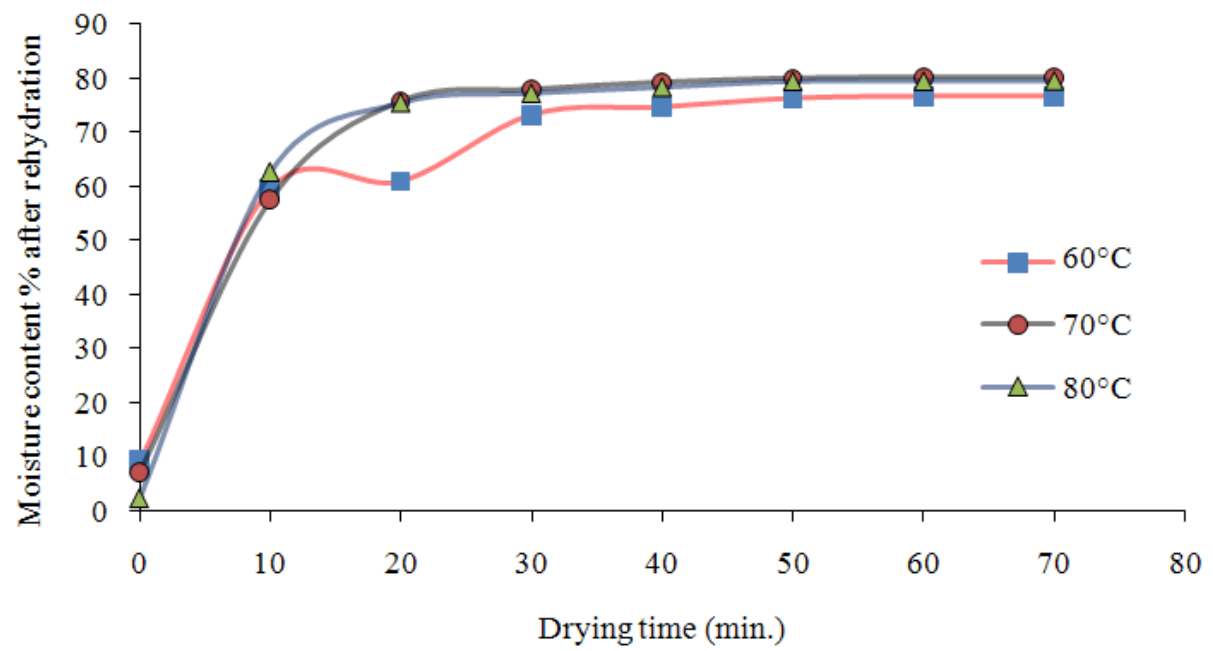

Fig. 13. Moisture content after rehydration for dried strawberry by halogen dryer at different temperaturs. vs. drying time

Table 3. Effect of using of different solvents and multiple periods on the antioxidative compounds activity in the strawberry

\begin{tabular}{|c|c|c|c|c|c|}
\hline \multirow[b]{2}{*}{ Solvents } & \multicolumn{5}{|l|}{ Periods (hr) } \\
\hline & 6 & 12 & 18 & 24 & 30 \\
\hline Ethyl acetate & $34 \pm 0.0120$ & $44 \pm 0.0131$ & $56 \pm 0.0102$ & $61 \pm 0.0154$ & $48 \pm 0.0213$ \\
\hline Methanol & $33 \pm 0.0098$ & $43 \pm 0.0114$ & $53 \pm 0.0132$ & $60 \pm 0.0241$ & $49 \pm 0.0132$ \\
\hline Propanol & $22 \pm 0.0097$ & $41 \pm 0.0111$ & $47 \pm 0.00891$ & $39 \pm 0.0301$ & $37 \pm 0.0213$ \\
\hline Ethanol & $31 \pm 0.0113$ & $38 \pm 0.0141$ & $37 \pm 0.0123$ & $35 \pm 0.016$ & $33 \pm 0.0211$ \\
\hline Chloroform & $30 \pm 0.0122$ & $37 \pm 0.0097$ & $37 \pm 0.00962$ & $37 \pm 0.0132$ & $37 \pm 0.0160$ \\
\hline Distilled water & $28 \pm 0.0132$ & $29 \pm 0.0131$ & $28 \pm 0.0123$ & $26 \pm 0.0213$ & $36 \pm 0.0142$ \\
\hline
\end{tabular}

Table 4. Reducing power for antioxidant compounds which extracted from the strawberry

\begin{tabular}{|c|c|c|c|c|c|}
\hline \multirow[b]{2}{*}{ Solvents } & \multicolumn{5}{|c|}{ Concentration $(\mathrm{mg} / \mathrm{mL})$} \\
\hline & 10 & 20 & 30 & 40 & 50 \\
\hline Ethyl acetate & $0.10 \pm 0.0010$ & $0.33 \pm 0.0019$ & $0.77 \pm 0.0010$ & $0.89 \pm 0.0011$ & $0.93 \pm 0.0031$ \\
\hline Methanol & $0.28 \pm 0.00102$ & $0.43 \pm 0.0124$ & $0.97 \pm 0.0010$ & $1.11 \pm 0.0021$ & $1.32 \pm 0.0021$ \\
\hline BHT & $0.32 \pm 0.0031$ & $0.55 \pm 0.0142$ & $1.12 \pm 0.0021$ & $1.72 \pm 0.0006$ & $1.91 \pm 0.0013$ \\
\hline
\end{tabular}


Table 5. Ability of antioxidant compounds which extracted from the strawberry to ferrous ion chelating.

\begin{tabular}{|c|c|c|c|c|c|}
\hline \multirow[b]{2}{*}{ Solvents } & \multicolumn{5}{|c|}{ Concentration $(\mathrm{mg} / \mathrm{mL})$} \\
\hline & 2 & 4 & 6 & 8 & 10 \\
\hline Ethyl acetate & $62 \pm 0.020$ & $69 \pm 0.032$ & $80 \pm 0.041$ & $82 \pm 0.021$ & $91 \pm 0.041$ \\
\hline Chloroform & $43 \pm 0.032$ & $49 \pm 0.023$ & $53 \pm 0.021$ & $59 \pm 0.032$ & $63 \pm 0.037$ \\
\hline 2Na-EDTA & $73 \pm 0.024$ & $79 \pm 0.021$ & $92 \pm 0.032$ & $92 \pm 0.053$ & $98 \pm 0.028$ \\
\hline
\end{tabular}

Table 6. Effect of antioxidant compounds inhibition by ethyl extract in the strawberry to retardation of antioxidant on corn oil to store periods

\begin{tabular}{|c|c|c|c|c|c|}
\hline \multirow{2}{*}{$\overline{\text { Extract concentrated }}$} & \multicolumn{5}{|c|}{$\begin{array}{l}\text { Peroxide value (mq/kg oil) } \\
\text { Stored period (day) }\end{array}$} \\
\hline & 10 & 20 & 30 & 40 & 50 \\
\hline 5 & $2.29 \pm 0.182$ & $4.27 \pm 0.041$ & $5.23 \pm 0.031$ & $10.10 \pm 0.010$ & $12.80 \pm 0.032$ \\
\hline 10 & $2.31 \pm 0.140$ & $3.60 \pm 0.020$ & $4.89 \pm 0.021$ & $9.15 \pm 0.022$ & $12.22 \pm 0.023$ \\
\hline 15 & $2.03 \pm 0.020$ & $2.57 \pm 0.041$ & $4.33 \pm 0.028$ & $7.00 \pm 0.013$ & $10.42 \pm 0.051$ \\
\hline 20 & $1.47 \pm 0.0172$ & $2.10 \pm 0.031$ & $2.93 \pm 0.031$ & $4.75 \pm 0.023$ & $8.10 \pm 0.035$ \\
\hline 25 & $1.44 \pm 0.0113$ & $1.53 \pm 0.019$ & $2.65 \pm 0.022$ & $4.05 \pm 0.012$ & $5.90 \pm 0.041$ \\
\hline BHT (2mg/gm) & $1.40 \pm 0.0251$ & $1.50 \pm 0.035$ & $1.74 \pm 0.021$ & $1.88 \pm 0.041$ & $2.37 \pm 0.031$ \\
\hline Control & $2.66 \pm 0.0211$ & $4.66 \pm 0.011$ & $5.44 \pm 0.050$ & $10.52 \pm 0.061$ & $13.03 \pm 0.061$ \\
\hline
\end{tabular}

Table 4 shows the ability of reducing power for antioxidant compounds which extracted from the strawberry. reducing power increased with increasing extracted concentration. This indicates that antioxidant compounds in strawberries have the ability to gave an electron which reacts with free radicals to convert the min to products more stable and thus ending the interactions of a series of free radicals.

Table 5 Shows the ability of strawberry extracted to connect the ferrous ion compared with 2 Na-EDTA using different concentrations. Results showed that high concentrations have a greater ability to binding, this means that the ability of the binding an increased with increasing used concentrations.

Table 6 shows the changes in the values of peroxide to corn oil during storage at $45^{\circ} \mathrm{C}$. the increase in the values of peroxide were dropped with increase the amount of added extracted. This indicates the ability of extracted of strawberry to impede the corn oil oxidation, but the impact of the antioxidant for extracted of strawberry was less than of which is for BHT, which completely reduced of corn oil oxidation at storage time of $45^{\circ} \mathrm{C}$. The purpose of this test is to identify the ability of antioxidant compounds in extracted strawberry. Be done recognition the degree of peroxides formation using ferricthaiocine method, the basis of this method is based on a complex formation of ferric ion interaction with the thaiocin. It is easy and sensitive methods to measurement of peroxides in the lipid (Shantha and Decker, 1994). The antioxidative activity exponentially increased as a function of the development of the reducing power, suggesting that the antioxidative properties can be associated with the development of the reducing power (Tanaka et al., 1990). Therefore, the effectiveness of antioxidant for strawberry extracted may be associated with reducing power. We conclude from the fore going that the ability of reducing power the ferrous ion can take a standard for the ability or antioxidant power for strawberry extracted. Sanchez-Moreno et al. (1999) stated that the extract can work to some extent as peroxides destroyers which react with hydroperoxides to give stable products by non radical processes besides antioxidant breaker which interfere with the free radical chain reaction.

\section{CONCLUSION}

The result of this study indicate that increasing drying temperature during the drying of strawberry increases the drying rate and drying coefficient and consequently decreases drying time. Also, the drying constant was greatly affected by drying temperature. Drying of strawberry slices occurred in falling rate period, no constant rate period was observed for the present study. The modified page model was found to be a better model for describing the characteristics of strawberry for both of the temperatures of 70 and $80^{\circ} \mathrm{C}$. The page model is found to be more reasonable for type of $60^{\circ} \mathrm{C}$ than the other models. The effective moisture diffusivity was found to average from $7.53 \times 10^{-9}-2.52 \times 10^{-8} \mathrm{~m}^{2} / \mathrm{sec}$. Temperature dependence of the diffusivity was related with Arrhenius type relationship. The efficiency was decreased with 
increasing drying temperature. The rehydration ratio was tested at $70^{\circ} \mathrm{C}$ is faster than other temperatures. The results showed that the moisture content ( $\mathrm{wb} \%)$ after rehydration reached to $76 \%$ at 70 an $80^{\circ} \mathrm{C}$ and reached to $70 \%$ at $60^{\circ} \mathrm{C}$. . The ability of reducing power of the ferrous ion can take as an indicator for the ability or antioxidant power for strawberry extracted.

\section{REFERENCES}

Akgun, N.A. and I. Doymaz, 2005. Modelling of olive cake thin-layer drying process. J. Food Eng., 68: 455-461. DOI: 10.1016/j.jfoodeng.2004.06.023

Akpinar, E.K., 2006. Mathematical modelling of thin layer drying process under open sun of some aromatic plants. J. Food Eng., 77: 864-870. DOI: 10.1016/j.jfoodeng.2005.08.014

Al-Hilphy, A.R.S., M.Z. Iscandar and K.H. Abid Alhassan, 2011. Astudy of drying some vegetables by halogen oven. Kufa J. Agric. Sci., 3: 209-216.

AOAC, 1984. Official methods of analysis of the Association of Official Analytical Chemists. 14th Edn., Association of Official Analytical Chemists, Arlington, ISBN-10: 0935584242, pp: 1141.

Arora, S., S. Bharti and V. K. Sehgal, 2006. Convective drying kinetics of red chillies. Dry. Technol., 24: 189-193. DOI: 10.1080/07373930600559068

Asami, D.K., Y.J. Hong, D.M. Barrett and A.E. Mitchell, 2003. Comparison of the total phenolic and ascorbic acid content of freeze-dried and air-dried marionberry, strawberry and corn grown using conventional, organic and sustainable agricultural practices. J. Agric. Food Chem., 51: 1237-1241. DOI: $10.1021 /$ jf020635c

Askari, G.R., Z. Emam-Djomeh and S.M. Mousavi, 2006. Effects of combined coating and microwave assisted hot-air drying on the texture, microstructure and rehydration characteristics of apple slices. Food Sci. Technol. Int., 12: 39-46. DOI: 10.1177/1082013206062480

Barbosa-Canovas, G.V. and H. Vega-Mercado, 1996. Other methods of dehydration of foods and packaging aspects. Dehydrat. Foods. DOI: 10.1007/978-1-4757-2456-1_9

Beaudry, C., G.S.V. Raghhavan, C. Ratti and T.J. Rennie, 2004. Effect of four drying methods on the quality of osmotically dehydrated cranberries. Dry. Technol., 22: 521-539. DOI: 10.1081/DRT-120029999

Crank, J., 1975. The Mathematics of Diffusion. 2nd Edn., Oxford University Press, Oxford, ISBN-10: 0198534116, pp: 414.

Demir, V., T. Gunhan and A.K. Yagcioglu, 2007. Mathematical modelling of convection drying of green table olives. Biosyst. Eng., 98: 47-53. DOI: 10.1016/j.biosystemseng.2007.06.011
Diamente, L.M. and P.A. Munro, 1993. Mathematical modelling of hot air drying of sweet potato slices. Int. J. Food Sci. Technol., 26: 99-109. DOI: 10.1111/j.1365-2621.1991.tb01145.x

Dimatteo, M.D., L. Cinquanta, G. Galiero and S. Crescitelli, 2000. Effect of a novel physical pretreatment process on the drying kinetics of seedless grapes. J. Food Eng., 46: 83-89. DOI: 10.1016/S0260-8774(00)00071-6

Doymaz, I., 2004. Convective air drying characteristics of thin layer carrots. J. Food Eng., 61: 359-364. DOI: 10.1016/S0260-8774(03)00142-0

El-Beltagy, A., G.R. Gamea and A.H. AmerEssa, 2007. Solar drying characteristics of strawberry. J. Food Eng., 78: 456-464. DOI: 10.1016/j.jfoodeng.2005.10.015

Evans, S.D., A. Brambilla, D.M. Lane, D. Torreggiani and L.D. Hall, 2002. Magnetic resonance imaging of strawberry (Fragaria vesca) slices during osmotic dehydration and air drying. LWU Food Sci. Technol., 35: 177-184. DOI: 10.1006/fstl.2001.0830

Gibbons, A. and I.A. Gray, 1998. Isolation by Planer Chromatography. In: Natural Product Isolation Cannel, P.J.R. (Ed.), Human Press, Totowa, ISBN10: 0896033627, pp: 209-245.

Henderson, S.M. and S. Pabis, 1961. Grain drying theory I: Temperature effect on drying coefficient. J. Agric. Eng. Res., 6: 169-174.

Kaya, A., O. Aydin, C. Demirtas and M. Akgun, 2007. An experimental study on the drying kinetics of quince. Desalination, 212: 328-343. DOI: 10.1016/j.desal.2006.10.017

Madamba, P.S. and F.A. Liboon, 2001. Optimization of the vacuum dehydration of celery (Apium graveolens) using the response surface methodology. Dry. Technol., 19: 611-626. DOI: 10.1081/DRT-100103938

Marquest, K.K., M.H. Renfore, P.B.B. Brevard, R.E. Lee and J.W. Gloeckrer, 2010. Differences in antioxidant levels of fresh, frozen and freeze-dried strawberries and strawberry jam. Int. J. Food Sci. Nutrit., 61: 759-769. DOI: 10.3109/09637481003796306

Meda, L. and C. Ratti, 2005. Rehydration of freeze-dried strawberries at varying temperatures. J. Food Process Eng., 28: 233-246. DOI: 10.1111/j.17454530.2005.00404.x

Midilli, A., H. Kucuk and Z. Yapar, 2002. A new model for single-layer drying. Dry. Technol., 20: 15031513. DOI: 10.1081/DRT-120005864

Muthukumaran, A., C. Ratti and V.G.S. Raghavan, 2008. Foam-mat freeze drying of egg white-mathematical modeling Part II: Freeze drying and modeling. Dry Technol., 26: 513-518. DOI: $10.1080 / 07373930801929615$ 
Orak, H.H., T. Aktas, H. Yagar, S.S. Isbilir and N. Ekinci et al., 2011. Antioxidant activity, some nutritional and colour properties of vacuum dried strawberry tree (Arbutus unedo L.) fruit. Acta Sci. Pol., Technol. Aliment., 10: 327-338.

Pallauf, K., J.C. Rivas-Gonzalo, M.D. Castillo, M.P. Cano and S.D. Pascual-Teresa, 2008. Characterization of the antioxidant composition of strawberry tree (Arbutus unedo L.) fruits. J. Food Comp. Anal., 21: 273-281. DOI: 10.1016/j.jfca.2007.11.006

Rangana, S., 1976. Manual of Analysis of Fruit and Vegetable Products. 1st Edn., Tata MaGraw-Hill, New Delhi, ISBN-10: 007096579X, pp: 634.

Sacilik, K., R. Keskin and A.K. Elicin, 2006. Mathematical modelling of solar tunnel drying of thin layer organic tomato. J. Food Eng., 73: 231238. DOI: 10.1016/j.jfoodeng.2005.01.025

Sanchez-Moreno, C., J.A. Larrauri and F.S. Calixto, 1999. Free radical scavenging capacity and inhibition of lipid oxidation of wines, grape juices and related polyphenolic constituents. Food Res. Int., 32: 407-412. DOI: 10.1016/S09639969(99)00097-6

Shantha, N.C. and E.A. Decker, 1994. Rapid, sensitive, iron-based spectrophotometric methods for determination of peroxide values of food lipids. J. AOAC Int., 77: 421-424. PMID: 8199478

Shishehgarha, F., J. Maklout and C. Ratti, 2002. Freezedrying characteristics of strawberries. Dry. Technol., 20: 131-145. DOI: 10.1081/DRT-120001370

SPSS, 2009. SPSS statistical package for window ver. 17. O. Chicago: SPSS, Inc.

Stanislaw, P., S.J. Digvir and C. Stefan, 1998. Grain Drying: Theory and Practice. 1st Edn., Willey, New York, ISBN-10: 0471573876, pp: 303.

Tahraoui, A., J. El-Hilaly, Z.H. Israili and B. Lyoussi, 2007. Ethnopharmacological survey of plants used in the traditional treatment of hypertension and diabetes in south-eastern Morocco (Errachidia province). J. Ethnopharm., 110: 105-117. DOI: 10.1016/j.jep.2006.09.011
Taiwo, K.A., M.N. Eshtiaghi, B.I.O. Ade-Omowaye and D. Knorr, 2003. Osmotic dehydration of strawberry halves: influence of osmotic agents and pretreatment methods on mass transfer and product characteristics. Int. J. Food Sci. Technol., 38: 693707. DOI: 10.1046/j.1365-2621.2003.00720.x

Tanaka, M., S. Sugita, W.K. Chiu, Y. Nagashima and T. Taguchi, 1990. Influence of water activity on the development of antioxidative effect during the Maillard reaction between histidine and glucose. Nippon Suisan Gakkaishi, 56: 525-530. DOI: 10.2331/suisan.56.525

Thorat, I.D., D. Mohaparta, R.F. Sutar, S.S. Kapdi and D.D. Jagtap, 2010. Mathematical modeling and experimental study on thin-layer vacuum drying of ginger (Zingiber officinale R.) Slices. Food Bioprocess Technol., 5: 1379-1383. DOI: 10.1007/s11947-010-0429-y

Toledo, R.T., 2007. Fundamentals of food process Engineering. 1st Edn., Springer, New York, ISBN10: 0387292411 , pp: 600.

Vagenas, G.K. and D. Marinos-Kouris, 2006. Drying kinetics of apricots. Dry. Technol., 9: 735-752. DOI: 10.1080/07373939108916707

Wang, C.Y. and R.P. Singh, 1978. A single layer drying equation for rough rice. ASAE.

Yakeda, Y., K. Fukumoto, M. Tchibana, Y. Shingu and T. Fugita et al., 2012. Monoterpene glycosides having a cross conjugated dienone system from spiraea can to niensis. Phytochem, 29: 1591-1591.

Yaldiz, O. and C. Ertekin, 2001. Thin layer solar drying of some vegetables. Dry. Technol., 19: 583-596. DOI: 10.1081/DRT-100103936

Yen, G.C. and H.Y. Chen, 1995. Antioxidative activity of various tea extracts in relation to their antimutagenicity. J. Agric. Food Chem., 46: 844854.

Yu, L., S. Haley, J. Perret and M. Harris, 2002. Antioxidant properties of hard winter wheat extracts. Food Chem., 78: 457-461. DOI: 10.1016/S0308-8146(02)00156-5 